\title{
Corrigendum: Mobile money and regional financial integration: Evidence from sub-Saharan Africa
}

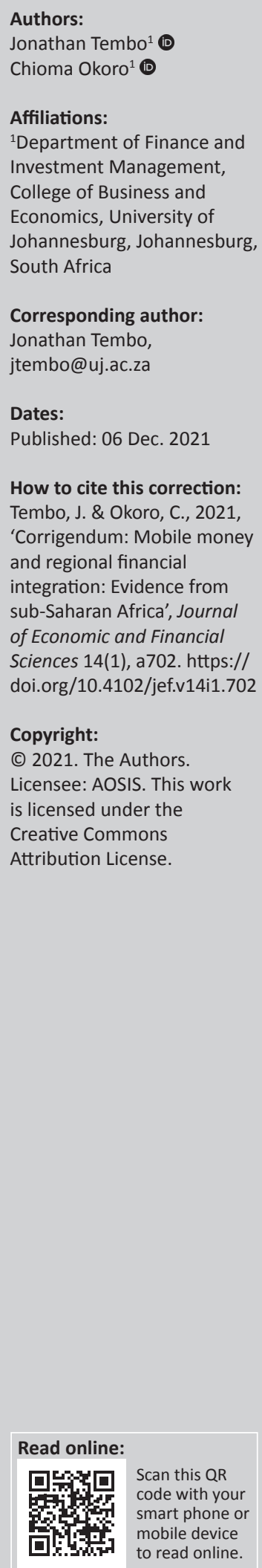

In the version of this article initially published, Tembo, J. \& Okoro, C., 2021, 'Mobile money and regional financial integration: Evidence from sub-Saharan Africa', Journal of Economic and Financial Sciences 14(1), a655. https://doi.org/10.4102/jef.v14i1.655, the authors' affiliation was given incorrectly in the 'Affiliations' sections. The correct affiliation should be 'Department of Finance and Investment Management, College of Business and Economics, University of Johannesburg, Johannesburg, South Africa' instead of 'Department of Finance and Investment, College of Business and Economics, University of Johannesburg, Johannesburg, South Africa'.

This correction does not alter the study's findings of significance or overall interpretation of the study's results. The authors apologise for any inconvenience caused. 


\section{Mobile money and regional financial integration: Evidence from sub-Saharan Africa}

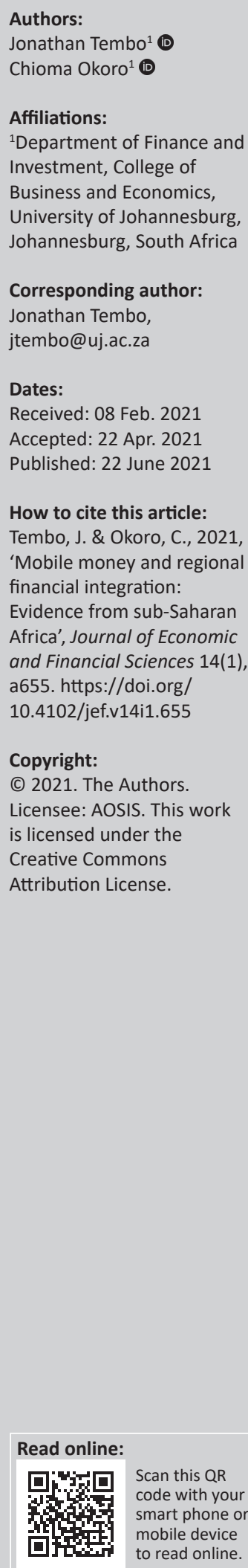

Orientation: The article examines the impact of mobile money adoption and regional financial integration in sub-Saharan Africa.

Research purpose: The study sought to uncover the relationship between mobile money adoption and cross-border remittances as a de facto measure of regional integration.

Motivation for the study: The extent to which differences in mobile money penetration rates across sub-Saharan Africa influence cross-border remittances remains a grey area that necessitates empirical investigation.

Research approach, design and method: A quantitative research method was adopted and the study examined aggregated quarterly data obtained from 41 countries making up the four regions of sub-Saharan Africa. The study applied the dynamic ordinary least squares and fully modified ordinary least squares approaches as the estimation techniques.

Main findings: Mobile money adoption has positively impacted cross-border remittances and improved de facto regional financial links in sub-Saharan Africa. The study's findings also support the view that better governance through control of corruption and political stability removes dependence on remittances.

Practical/managerial implications: There is a need to integrate mobile money and other crossborder remittance platforms to improve access to financial services for migrants and harness their savings into the mainstream economy.

Contributions/value-add: The study adds to the body of knowledge by showing that higher mobile money penetration rates have regional integration benefits.

Keywords: mobile money; regional financial integration; sub-Saharan Africa; cross-border remittances; migrants.

\section{Introduction}

The advancement of technology has brought along a new form of financial services known as fintech. This study adopts Mention's (2019) definition of fintech as innovative and technologyenabled financial services and their associated business models. In sub-Saharan Africa, fintech advancement has mainly been in the form of mobile money. Mobile money represents a fintech innovation that uses mobile phones to provide financial services. Globally, the sub-Saharan African region has been identified as the leader in mobile money usage and adoption (Sy et al. 2019). The GSMA (2019a) agreed with this assertion placing sub-Saharan Africa's adoption of mobile money at $45 \%$, followed by South Asia at 33\%. In contrast, low adoption rates are observed in other regions, with Europe and Central Asia and Latin America and the Caribbean having adoption rates of $1.4 \%$ and $3.1 \%$, respectively (GSMA 2019a). The high adoption rates in subSaharan Africa have seen the region having mobile money accounts surpassing bank accounts (Sy 2019). Reasons for the high adoption rates vary. Whilst Naghavi (2019) attributed the high adoption rate to more enabling regulatory environments, Mothobi and Grzybowski (2016) and Jong-Moon and Hyunju (2016) suggested the minimal financial services infrastructure required for mobile banking in both rural and urban areas could be behind the high adoption rates.

On the other hand, Sy (2019) considered the increasing number of services accessible across mobile money platforms such as savings accounts, mobile banking, loans and insurance services as attractive features drawing a greater number of sub-Saharan Africans towards the service. In this regard, mobile money is seen as a gateway to financial inclusion by a largely excluded populace. The UNCTAD (2018) acknowledged that most Sub-Saharan African countries are interconnected through migration corridors, and these corridors are 
largely dominated by undocumented migrants and informal traders who cannot access formal financial services. Therefore, increased digitalisation of financial services through mobile money offers the opportunity for increased access to financial services and a secure and formal way of transferring funds across borders for these undocumented migrants and informal traders. Based on this, there is a need to shed light on the extent to which regional financial links, namely cross-border flows and remittances, have been impacted by the rise in mobile money adoption.

\section{Background to the study}

Technological innovation has charted the history of mankind over time. Through it, societies and economies have been shaped, remodelled and reinvented. With the advent of the Fourth Industrial Revolution, the world finds itself at the cusp of another technological reinvention. The Fourth Industrial Revolution has brought with it fundamental changes, including increased automation, enhanced intelligence and instantaneous connection (IFC 2019). Such disruptive inventions are expected to have farreaching impact on every industry, including the financial services sector. Some of the impacts include increased access to financial services, especially for unbanked communities (Buchak et al. 2018; Philippon 2019). This is especially true for developing countries that supposedly have the highest number of financially excluded people. A study by Demirgüç-Kunt, Klapper and Bank (2012) showed three out of four adult Africans did not have a bank account, and the majority of adult Africans use informal channels for saving and borrowing. Furthermore, most of the small and medium enterprises did not use formal banking channels and had difficulties in accessing financial services (Demirgüç-Kunt et al. 2012).

However, a later study by Asuming, Osei-Agyei and Mohammed (2019), with a focus on sub-Saharan Africa, showed a notable increase in the levels of financial inclusion up to the year 2014 with Pasti (2017) and the International Finance Corporation (IFC 2018) identifying mobile money as the main catalyst for growth in financial inclusion. Regional economic hubs such as South Africa and Kenya indeed do show high levels of financial inclusion connected with improvements in fintech (Villasenor, West \& Lewis 2015). Given the regional interconnectedness of African countries through migrant movement, increased access to financial services through mobile money should result in a corresponding rise in cross-border remittance flows and, in turn, improve regional financial links between countries. However, despite improvements in financial inclusion, Villasenor et al. (2015) claimed usage of these financial services is still low, whilst Sy et al. (2019) had evidence to the contrary. This brings into question the impact of mobile money in improving cross-borders remittance flows and, in turn, enhancing regional links in sub-Saharan Africa.

\section{Overview of mobile money penetration in sub-Saharan Africa}

The origins of mobile money in sub-Saharan Africa date back to the year 2000 when the first mobile money service was launched in South Africa (Jong-Moon \& Hyunju 2016). However, the region's mobile money landscape changed when Kenya's mobile network operator Safaricom introduced M-Pesa in 2007. Mobile-Pesa (M-Pesa) is the world's largest mobile money service with over 47 million active customers (Vodafone 2020). It has agents in six Sub-Saharan African countries and its services are accessible in 19 African countries (Vodafone 2020). In the region, M-Pesa faces competition from Mobile Telephone Network (MTN) mobile money and Orange. MTN mobile money services are accessible in 15 Sub-Saharan African countries, whilst Orange has established itself in 17 countries within the region (MTN 2020; Orange 2020). Consequently, in sub-Saharan Africa, mobile money has grown faster than in other regions, as depicted (Figure 1).

The sub-Saharan African region dominates in all the mobile money metrics. According to the GSMA (2019b) metrics, the region has 470 million registered mobile money accounts, the highest in the world. South Asia and East Asia and Pacific come second and third with 315 and 157 million registered accounts, respectively. The accounts metrics are lower when it comes to active accounts. Of the 470 million registered accounts in sub-Saharan Africa, only 180 million are active. The same trend is observed in other regions, an indicator of disparity between registered accounts and usage. The gulf between sub-Saharan Africa and other regions is more evident when transaction volumes and values are considered. The volume of transactions for the region was 2.11 billion, whilst South Asia was a distant second with 663 million transactions. The remaining four regions had 537 million mobile money transactions in total, showing clearly the service has not taken off to the same extent as sub-Saharan Africa. In terms of value, $\$ 41.5$ billion went through the

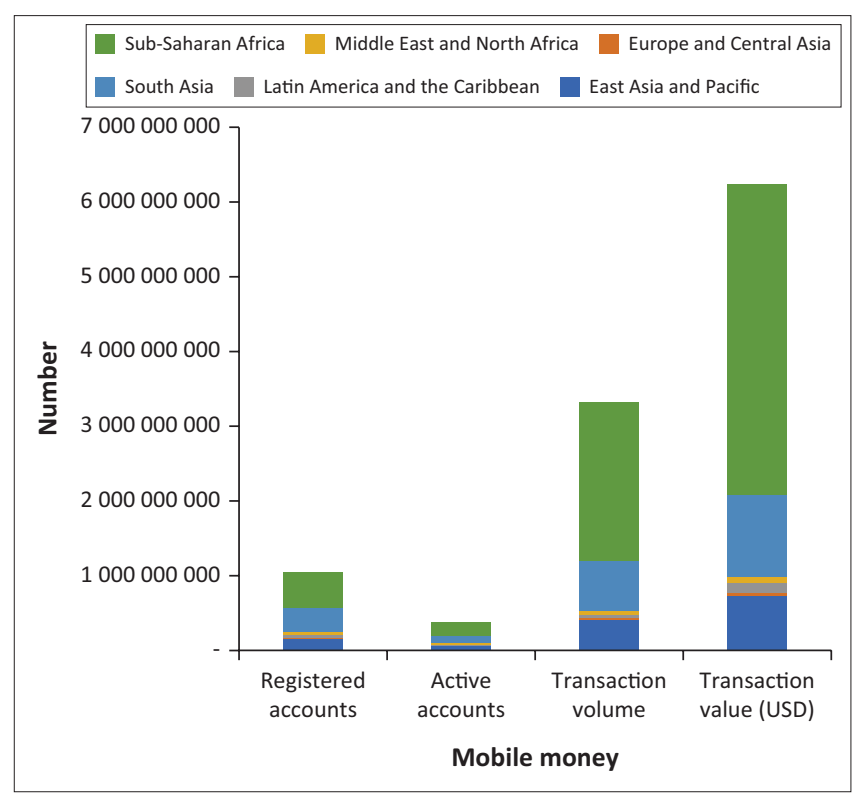

FIGURE 1: Global mobile money. 
sub-Saharan Africa mobile money system, with South Asia following at $\$ 11 \mathrm{bn}$. East Asia and the pacific came third with transactions worth $\$ 732$ million. Mobile banking has proved to be a convenient alternative, where access to banking accounts is difficult. Thus, raising levels of financial inclusion with limited documentation restrictions (Rea \& Nelms 2017).

The extent to which mobile money penetration has improved access to financial services across Sub-Saharan African countries is shown (Figure 2). The regional average for those with a bank or mobile account is $50 \%$ of the total population aged 15 years or greater. In terms of access to traditional banking, the same population can only access five bank branches per 100000 people. Eastern Africa leads with an average mobile subscription of 77 per 100 people and bank or mobile account of 66 per 100 people. Within sub-Saharan Africa, Kenya has the highest bank or mobile account penetration of $88 \%$, possibly as a result of being the focal point for mobile money in the region through M-Pesa. Other Eastern Africa countries such as Uganda and Rwanda follow suit with high bank or mobile account penetration rates of $67 \%$ and $57 \%$, respectively. In terms of mobile money penetration, West African countries such as Ghana and the Ivory Coast remain sleeping giants as they have mobile cellular subscriptions, which are not translating to the same figures in terms of mobile money. The extent to which such differences in penetration rates influence crossborder flows and remittances still remains a grey area necessitating the current empirical investigation. However, the World Bank (2018) and GSMA (2018) identified four

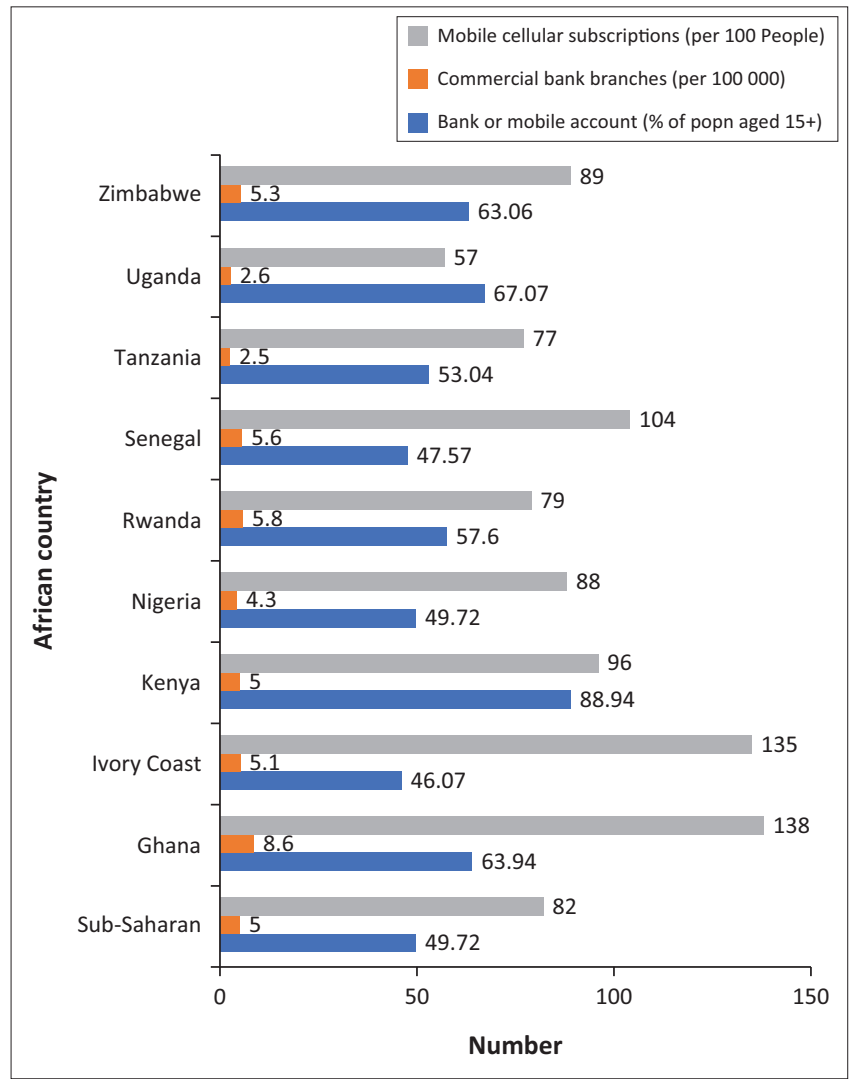

FIGURE 2: Mobile accounts and bank access. channels through which international remittances manifest, namely banking institutions, money transfer organisations, mobile money platforms and informal channels. With the emergence of new digital platforms, banks have seen their share of remittances market share shrink from 33\% in 2011 to $22 \%$ by 2018 (World Bank 2018). During the same period, the share of international remittances sent through mobile money in low- to middle-income countries has risen to $15 \%$. However, in Sub-Saharan African countries such as Uganda, Zimbabwe and Ghana, the share appears greater as $33 \%$ of remittances are now paid out as mobile money (GSMA 2018). Furthermore, in West African countries such as Burkina Faso and Ivory Coast, the total value of crossborder remittances has exceeded the value of estimated international remittances because of the emergence of Orange Money, proving that mobile money has also captured remittances, which were going through informal channels (GSMA 2018). This is mainly attributed to the low cost of sending money through mobile money, which stands at $1.7 \%$ for sending $\$ 200$, well below sustainable development goals rate of $3 \%$. Consequently, in subSaharan Africa, there are 53 corridors through which international remittances can be received through mobile money (GSMA 2018).

\section{Statement of the problem}

With the adoption of disruptive technology being a global phenomenon, sub-Saharan Africa has not been spurred. Of the various forms of Fintech on offer, mobile money has come up as the most preferred technological innovation in the region, evidenced by a $40 \%$ adoption rate, the highest in the world (Pasti 2017; Sy et al. 2019). According to UNCTAD (2018), interregional migration is a key feature in Africa, with $80 \%$ of migrants in Eastern, Middle and Western Africa having originated from the same region and the Ivory Coast, Kenya and South Africa serving as the migration hubs. Such a situation presents an opportunity for increased use of mobile money as migrants transfer funds across borders. Such transfer of funds across borders are expected to increase cross-border flows and remittances and in turn, improve regional financial integration amongst Sub-Saharan African countries. Mobile money adoption in sub-Saharan Africa has shown impressive growth with over 100 million active accounts (GSMA 2019b). Another study by FinMark Trust (2016) not only acknowledged the expansion of mobile money but also observed that migration corridors continue to be served by informal agents. Furthermore, the extent to which differences in mobile money penetration rates influence cross-border flows and remittances still remains a grey area. This puts into question the impact of mobile money on enhancing regional financial integration through improved cross-border flows and remittances and necessitated an empirical investigation into these areas.

\section{Objectives of the study}

The primary objective of the study was to determine the impact of mobile money on regional financial integration. 
The secondary objectives of the study were to:

1. determine the impact of mobile money usage on crossborder remittances

2. uncover the relationship between migration patterns and cross-border remittances

3. to examine the relationship between cross-border remittances and quality of governance.

\section{Literature review}

This section reviews the main theoretical and empirical literature underlying the subject under study.

\section{Mobile money as fintech innovation}

Fintech refers to the use of technology to find solutions to financial problems or to provide financial services (Arner, Barberis \& Buckley 2016). Fintech is part of the global technological transformation, which has gripped the world since the year 2014. As being formally introduced as a form of disruptive technology, fintech has grown in adoption amongst global consumers with Ernst \& Young (EY) (2019) setting the fintech global adoption index at $64 \%$. The different categories of fintech include money transfer and payments services, lending, insurance, digital currencies, savings and investment, amongst others (Dorfleitner et al. 2017). Of these, mobile phone payment platforms are the most popular, with $89 \%$ of global consumers aware of at least one mobile phone payment platform (EY 2019). In emerging markets, mobile money has emerged as the most adopted fintech platform and the main platform for accelerated access to financial services for unbanked populations (Mastercard 2018; Nantege 2015; Pasti 2017). Mobile money represents a digital form of electronic money, which is used on mobile telephony devices (Diniz, Porto de Albuquerque \& Cernev 2017). It allows for peer-to-peer transfer of electronic money even across borders. It is this aspect of transferability that makes mobile money attractive to consumers, especially migrants. As such, mobile money has become a very useful instrument for the facilitation of cross-border and international remittances (FinMark Trust 2016). The extent to which such flows have improved financial links amongst regional countries has not been fully explored, hence the need to conduct this study.

\section{Theoretical perspective of technology}

Technological innovation has been part of human history since the first industrial revolution when the steam engine was invented. As a result, societies' cultural norms and economic structures have tended to adapt to the technological innovations taking place at the time. The theoretical perspective of technology attempts to explain the main considerations for the adoption or use of new technology and links it to current trends where fintech is replacing older technology. The most prominent of these theories include the technological acceptance model (TAM), unified theory of acceptance and technology (UTAT), adaptation level theory (ALT) (Marshall 2007). The main focus points of these theories are that technology will be adopted because of its perceived ease of use, perceived usefulness, performance expectancy, social influence, age, amongst other factors (Marshall 2007). A review of the main drivers of fintech adoption as observed by EY (2019), such as ease of setting up accounts, access to different products, better experience and better products, confirms that the technological usage theories are still relevant in explaining the adoption of fintech.

\section{Migration, remittances and mobile money: Empirical evidence}

Early empirical studies on mobile money and migration have largely depicted mobile money as a solution provider to migrants in need of transferring funds across countries. For instance, Mirabaud (2009), Batista and Vicente (2014), David, Dana and Abel (2013) have attested to the positive impacts of mobile money on migrant remittances. Mirabaud (2009) investigated mobile money as a remedy for the transfer of migrant funds in the Philippines and Kenya using secondary data from case studies and other reports. The study revealed the positive impacts of migrant funds transferred through mobile money occur at three levels, which are economic, community and individual. Similarly, Batista and Vicente (2014) examined how mobile money introduction in Mozambique had shaped financial behaviour in the country. The study's findings showed a favourable approach to remittances with increased usage of mobile money. Furthermore, the findings revealed a shift from previous remittance platforms towards mobile money and adoption of mobile money for additional financial services such as savings. However, the findings by Batista and Vicente (2014) did not cover the motives behind remittances by migrants. In contrast, David et al. (2013) examined the motives for migrant remittances using mobile money.

The findings showed that migrants have a tendency to remit more to themselves than to other parties, with the bulk of remittances going towards personal savings instead of serving the well-being of others. David et al. (2013) based their findings on remittances from migrants in France and none from countries in sub-Saharan Africa. Therefore, there may be differences in motives arising from where the migrants are based. Another study by Kikulwe, Fischer and Qaim (2014) focussed on the impact of mobile money remittances from a smallholder farmer perspective. The study's results confirmed the positive attributes of mobile money in terms of reducing risk for Kenyan smallholder farmers, raising liquidity levels, increasing income and enabling smallholder farmers to purchase inputs. In addition, Aker and Wilson (2013) also studied mobile money adoption from a rural perspective in Northern Ghana through an action-oriented research providing interventions, which reduce barriers to accessing mobile money in rural Ghana.

The study showed participants who had improved access to mobile phones and in turn, mobile money had more access to remittances from migrants and would go even further in 
using mobile money to access other financial services such as savings. These early studies appeared to focus more on the impact of mobile money migrant remittances at the household and individual level and failed to capture the economic integration ramifications that may arise from mobile money remittances, which this study attempts to address. Again the studies were carried out when mobile money technology was in its formative stage in developing countries. As such, more recent studies, including Munyegera and Matsumoto (2016), Batista and Vicente (2020) and Aker, Prina and Welch (2020) appeared to show mixed results in terms of the nature of the impact. Munyegera and Matsumoto (2016) assessed the household effect of mobile money remittances in Uganda with a greater focus on rural households. The study adopted panel data and instrumental variables approach to show the extent to which household welfare of rural Uganda had been impacted by increased uptake of mobile money. The study's findings confirmed the positive effect of mobile money usage on remittances. Households that adopt mobile money were observed to have a greater probability of receiving remittances. There were also differences in the volumes of remittances between mobile money users and non-mobile money users. Households that adopted mobile money were observed to have higher volumes of remittances as opposed to those that have not adopted mobile money (Munyegera \& Matsumoto 2016).

However, a study by Batista and Vicente (2020) appeared to contradict the narrative of only positive effects arising from mobile money and migrant remittances. The study carried out by Batista and Vicente (2020) in rural Mozambique showed mixed results with mobile money remittances observed to improve consumption and reducing the vulnerability of mobile money users to shocks against extreme weather conditions such as floods. The study also showed mobile money remittances had the effect of slowing down agricultural activity and investment in rural Mozambique as the remittances provided greater insurance options for the rural households. Such results seem to suggest long-distance mobile money remittances may not always have positive effects, as highlighted in earlier studies.

On the other hand, Aker et al. (2020) investigated mobile money and remittances in terms of benefits to the sender as opposed to the receiver as in previous studies. Their findings showed that mobile money has remittance cost advantages to senders when compared with other remittance transfer platforms. The study attributed the low usage of mobile money in West Africa to infrastructure shortages. However, the study did not show the extent to which mobile money impacted cross-border remittances within the West Africa region. Kirui (2020) examined the effect of mobile money adoption on international remittances for sub-Saharan countries. The study used a Generalised Method of Moments (GMM) model and findings showed mobile money services adoption had no effect on international remittances. Similar results were obtained when the remittance amount was replaced by the remittance fee as the proxy for international remittances. However, Kirui's (2020) findings appeared to be contradictory as the study's findings also showed a decrease in international remittances from sub-Saharan Africa relative to the rest of the world. The same study attributed such a decrease to the use of mobile money in informal cross-border remittances. Therefore, whilst mobile money was observed to reduce international remittances, the effect on cross-border remittances was suggestively observed to be incremental. Such contradictions present a gap to conclusively determine the extent to which cross-border flows have been impacted by mobile money.

\section{Remittances and quality of governance}

Empirical studies on the relationship between remittances and governance have largely focussed on the extent to which remittances influence the latter. For instance, Ahmed (2013) examined the impact of remittances on non-oil producing Muslim countries. The study revealed a negative impact of remittances on governance as governments take advantage and cease providing public welfare services such as healthcare. Ahmed (2013) argued that in countries with weak institutions, governments divert funds meant for public services as the availability of remittances eases the pressure to provide public services. Similarly, Tyburski (2014) assessed the impact of remittances in the developing world and suggested that the economic impact of remittances depends on the regime in a specific country. In countries with largely authoritarian regimes, remittances may have a negative impact as the regimes may replace public services spending with private spending (Tyburski 2014). As such, in authoritarian regime countries with weak institutions, an increase in remittances is largely associated with an increase in levels of government corruption. On the other hand, Tyburski (2014) also observed that in countries with more democratic space, remittances might instead empower individuals to demand more accountability from their governments. The increase in income from remittances and reduced dependence on governments allow citizens to express themselves more freely and demand greater transparency in government activity, which in turn may reduce levels of corruption (Tyburski 2014). Ricciardulli (2019) took a different approach and used an instrumental variables method to determine the impact of remittances on government expenditure on public services. The findings of the study also supported the narrative that governments may substitute public spending for private spending in the case of increased remittances. In contrast, Bearce and Park (2019) used an error correction model and found that remittances may increase the demand for political accountability instead of reducing it. Bearce and Park (2019) argued that remittances increase incomes not only of those who receive them but even the incomes of the working class who do not receive them, through the multiplier effect. As such, remittances increase national economic assets. In a new democratic model with different sociateal groups, such an increase results in a rise in demand for accountability to protect these national assets by different groups. Ajide and 
Olayiwola (2020) concurred with Bearce and Park (2019) and using an Autoregressive Distributed Lag (ARDL) model confirmed that remittances can be used to control levels of corruption. However, the studies do not show the extent to which the flow of remittances is influenced by the quality of governance in specific countries. It is important to find out if the level of remittances increases with an improvement in the quality of governance in a country. Ajide and Raheem (2016) examined the other side of the relationship and investigated the impact of institutional quality on remittances in the Ecowas region. Their findings uncovered the positive response of remittances to higher institutional quality levels except for economic and political governance indicators. Unlike this study, Ajide and Raheem (2016) limited their study to countries in West Africa. It will be interesting to find out if their findings will also apply to the rest of sub-Saharan Africa.

\section{Methodology}

The study sought to determine the extent to which mobile money usage has improved financial links between Sub-Saharan African countries through cross-border remittances. In this regard, the study adopted a quantitative research design, which used numerical data comprising cross-border remittances, registered mobile money users in sub-Saharan Africa, stock of migrants in the selected sub-Saharan Africa countries and selected governance indicators.

\section{Sources of data}

The study used data from various public domains. Data on cross-border remittances and mobile money registered accounts were obtained from the GSMA database. Data on the stock of migrants in sub-Saharan Africa and quality of governance indicators such as the rule of law (ROL), control of corruption, political stability and absence of violence were obtained from the World Bank database. The UNCTAD database provided trade openness (TO) and gross domestic product (GDP) indicators. The data were collected from the four regions making up sub-Saharan Africa in line with GSMA regional allocation. The countries and their allotted regions are shown (Table 1$)$.

\section{Estimation model}

A panel model was applied with cross-border remittances as the dependent variable in line with Ajide and Raheem (2016) and Apiors and Suzuki (2018). The model tries to capture the effects of mobile money adoption on the volumes of crossborder remittances across borders. Therefore, the model captures the impact of the intensity of mobile money adoption in the context of sub-Saharan Africa. The panel was made up of four regions from sub-Saharan Africa with quarterly aggregate data from each region used in the model. The study covered a 9-year period running from 2011 to 2019. A total of 144 observations were thus obtained. The model specification was as follows:

$$
\begin{aligned}
\text { REMM }_{i t}= & \alpha_{0}+\alpha_{1} R E G_{i t}+\alpha_{2} M_{I G R_{i t}+\alpha_{3} R O L_{i t}+\alpha_{4} P O L_{i t}+} \\
& \alpha_{5} \operatorname{CORR}_{i t}+\alpha_{6} T O_{i t}+\alpha_{7} G D P_{i t}+\epsilon_{i t} \cdots
\end{aligned}
$$

Where REMM represents cross-border peer-to-peer remittance flows from the sub-Saharan African regions. This is a de facto indicator of the extent of regional integration amongst subSaharan African regions as it shows the extent of financial links between countries at an individual level through remittance flows. De facto indicators measure the extent of financial integration through the flow of assets and liabilities across countries (Bush 2015; Gehringer 2014). The main explanatory variable $R E G$ denotes the number of mobile money registered accounts in each region and was taken as the measure of mobile money usage in sub-Saharan Africa in line with Mahmoud (2019). Stock of migrants (MIGR) was used as a representative of migration across countries with the stock of international migrants adopted for this study drawn from previous studies (Ziesemer 2009). The study

\begin{tabular}{|c|c|}
\hline Region & Country \\
\hline \multirow[t]{14}{*}{ Eastern Africa } & Burundi \\
\hline & Ethiopia \\
\hline & Kenya \\
\hline & Madagascar \\
\hline & Malawi \\
\hline & Mauritius \\
\hline & Mozambique \\
\hline & Rwanda \\
\hline & Seychelles \\
\hline & Somalia \\
\hline & South Sudan \\
\hline & Sudan \\
\hline & Tanzania \\
\hline & Uganda \\
\hline \multirow[t]{6}{*}{ Central Africa } & Cameroon \\
\hline & Central African Republic \\
\hline & Chad \\
\hline & Congo \\
\hline & Democratic Republic of Congo \\
\hline & Gabon \\
\hline \multirow[t]{7}{*}{ Southern Africa } & Botswana \\
\hline & Eswatini \\
\hline & Lesotho \\
\hline & Namibia \\
\hline & South Africa \\
\hline & Zambia \\
\hline & Zimbabwe \\
\hline \multirow[t]{14}{*}{ West Africa } & Benin \\
\hline & Burkina Faso \\
\hline & Cote d’Ivoire \\
\hline & Gambia \\
\hline & Ghana \\
\hline & Guinea \\
\hline & Guinea Bissau \\
\hline & Liberia \\
\hline & Mali Mauritania \\
\hline & Niger \\
\hline & Nigeria \\
\hline & Senegal \\
\hline & Sierra Leone \\
\hline & Togo \\
\hline
\end{tabular}

TABLE 1: Sub-Saharan African countries by region 
adopted three governance quality indicators, namely ROL, political stability and absence of violence (POL) and control of corruption (CORR). The percentile rank of each governance indicator was applied, with 0 being the highest and 100 being the lowest. The selected governance indicators have been applied as governance quality measures in previous studies (Asongu \& Odhiambo 2019; Effiong \& Asuquo 2016; Ogunniyi et al. 2020). The model also included TO measured through the average exports and imports at current prices and the GDP at current prices as control variables.

\section{Estimation techniques}

The study applied the dynamic ordinary least squares (DOLS) and fully modified ordinary least squares techniques (FMOLS) to estimate the relationship between cross-border remittances, mobile money registration and the respective explanatory variables. The DOLS and FMOLS are panel cointegration techniques based on works by Phillips and Moon (1999), Pedroni (2000), Stock and Watson (1993) and Kao and Chiang (2000). The DOLS and FMOLS estimators are consistent estimators for integrated variables even when there is endogeneity and serial correlation (Phillips \& Hansen 1990; Stock \& Watson 1993). The DOLS uses a parametric approach in its estimation for cointegrating vectors, whilst the FMOLS uses a non-parametric approach. However, it has been observed that both methods produce unbiased and normally distributed coefficients under different conditions (Pedroni 2000). The study also considered the pooled mean group (PMG) approach by Pesaran, Shin and Smith (1999), which allows for homogeneity in the long-run coefficients and heterogeneity in the short-run. However, the DOLS and FMOLS were selected on the basis of their ability to better correct for serial correlation and endogeneity and allow for normal inference in a cointegrated panel framework. The basic requirements for the application of DOLS and FMOLS estimations are that all variables must have I(1) integration. Therefore, variables fit for the estimations must have unit root at level that dissipates after first differencing. In this study, panel unit root tests were conducted through the Levin, Lin and Chu (2002) test and Fisher-ADF test (Maddala $\& W u$ 1999). After unit root tests, the next stage will be checking for the existence of a long-run relationship amongst the variables through cointegration tests. This study applied the Kao (1999) tests of cointegration. The Kao test assumes a homogenous panel and has a no cointegration null hypothesis. In the event that there is cointegration, the DOLS and FMOLS estimations can then be conducted. As cointegrated variables may have a causality effect on each other in one direction or both, the study also tested for Granger causality between mobile money, cross-border remittances and the other explanatory variables through the Dumitrescu-Hurlin (2012) test.

\section{Preliminary findings}

This section presents findings on the preliminary results, including cross-sectional dependence tests, unit root tests and cointegration tests.
The descriptive statistics of variables applied in the study is shown (Table 2). The mean for cross-border remittances was $\$ 1.5 \mathrm{bn}$ whilst the maximum remittances recorded in the sub-Saharan African region was $\$ 9.8 \mathrm{bn}$. The standard deviation (SD) of $\$ 2.31 \mathrm{bn}$ for remittances was greater than the mean suggesting great variability in the level of remittances. The maximum number of registered mobile money accounts recorded in sub-Saharan Africa was 249 million, with the mean of mobile money registered accounts being 60.41 million. The highest stock of international migrants recorded was 6.6 million whilst the mean for international migrants' stock stood at 4.24 million. In terms of quality of governance, all the means for the three governance indicators were below 50, indicating poor governance quality across sub-Saharan Africa. The highest percentile rank obtained in terms of governance was 56.16 for political stability and absence of violence, followed by 45.2 for control of corruption. The SD for the governance indicators was significantly lower than the mean suggesting uniformity in terms of quality of governance across sub-Saharan Africa.

Cross-sectional dependence tests were carried out to check if units in the same cross-section are correlated. Dependence usually arises from unobserved effects such as similar economic policies. In this study, the tests were performed through Breusch-Pagan LM (1980), Pesaran Scaled LM (2004), Bias Corrected LM test (Pesaran, Ullah \& Yamagata 2008) and the Pesaran CD test (Pesaran 2004). All test results rejected the null of no cross-sectional dependence. Cross-sectional dependence was therefore taken into account in the estimation techniques applied.

All variables were observed to have unit root at level and were stationary after first differencing. Therefore, all the variables were said to be integrated of order (1). The next step involved checking for cointegration to establish if a long-run relationship existed amongst the variables.

TABLE 2: Descriptive statistics of variables.

\begin{tabular}{lcccccccc}
\hline Variable & $\begin{array}{c}\text { REMM } \\
\text { (\$M) }\end{array}$ & $\begin{array}{c}\text { REG } \\
\text { (Million) }\end{array}$ & $\begin{array}{c}\text { MIGR } \\
\text { (Million) }\end{array}$ & $\begin{array}{c}\text { TO } \\
\text { (\$M) }\end{array}$ & $\begin{array}{c}\text { GDP } \\
\text { (\$M) }\end{array}$ & CORR & POL & ROL \\
\hline Mean & 1510 & 60.41 & 4.24 & 104791.4 & 355489.2 & 30.92 & 36.88 & 31.49 \\
Median & 371 & 30.23 & 4.16 & 109504.5 & 328781.5 & 34.96 & 33.14 & 34.32 \\
Maximum & 9800 & 249 & 6.6 & 153040 & 629939 & 45.2 & 56.16 & 40.14 \\
Minimum & 1.01 & 0.26 & 2.05 & 58974 & 123784 & 10.58 & 21.19 & 13.46 \\
SD & 2310 & 70.13 & 1.690 & 30291.78 & 131945.5 & 11.19 & 11.49 & 8.82 \\
- & - & - & - & - & - & - & - & - \\
Observations & 144 & 144 & 144 & 144 & 144 & 144 & 144 & 144 \\
\hline
\end{tabular}

REMM, cross border remittances; REG, number of mobile money registered accounts; MIGR, stock of migrants; TO, trade openness; GDP, gross domestic product; CORR, control of corruption; POL, political stability and absence of violence; ROL, rule of law; SD, standard deviation.

TABLE 3: Cross-sectional dependence tests.

\begin{tabular}{lcc}
\hline Test & Statistics & Probability \\
\hline Breusch-Pagan LM & 18.35350 & 0.0054 \\
Pesaran Scaled LM & 3.566148 & 0.0004 \\
Bias-Corrected LM & 3.509005 & 0.0004 \\
Pesaran CD & -0.058426 & 0.9534 \\
\hline
\end{tabular}


TABLE 4a: Unit root and cointegration tests.

\begin{tabular}{|c|c|c|c|c|}
\hline \multirow[t]{2}{*}{ Variable } & \multicolumn{2}{|c|}{ Level } & \multicolumn{2}{|c|}{ First difference } \\
\hline & Levin, Lin, Chu & Fisher-ADF & Levin, Lin, Chu & Fisher-ADF \\
\hline REMM & -0.90687 & 4.80839 & $-21.3018 * * *$ & $33.9852 * * *$ \\
\hline REG & -1.59244 & 5.43214 & $-5.05526 * * *$ & $13.3597^{*}$ \\
\hline MIGR & 1.56990 & 3.22673 & $-4.52609 * * *$ & 8.46009 \\
\hline TO & -1.87088 & 13.0642 & $-5.91766 * * *$ & $15.7711 * *$ \\
\hline GDP & 1.11435 & 8.10115 & $-9.48536 * * *$ & $24.6923 * * *$ \\
\hline CORR & -1.23974 & 12.9683 & $-5.39174 * * *$ & $21.5511 * * *$ \\
\hline POL & -0.14685 & 2.40733 & $-5.21013 * * *$ & $20.2489 * * *$ \\
\hline $\mathrm{ROL}$ & 0.47516 & 2.39753 & $-4.68549 * * *$ & $21.5574 * * *$ \\
\hline
\end{tabular}

REMM, Cross border remittances; REG, number of registered mobile money accounts; MIGR, stock of migrants; TO, trade openness; GDP, gross domestic product; CORR, control of corruption; POL, political stability and absence of violence; ROL, rule of law; HAC, Heteroskedasticity and Autocorrelation Consistent; ADF, Augmented Dickey-Fuller.

$*, * *, * * *$, Indicates significance at $1 \%, 5 \%, 10 \%$, respectively.

TABLE 4b: Unit root and cointegration tests.

\begin{tabular}{lcc}
\hline \multicolumn{3}{c}{ Kao cointegration tests } \\
\hline Series & ADF $t$ statistic & Prob \\
\hline REMM REG MIGR TO GDP CORR POL ROL & $-4.575999 * * *$ & 0.0000 \\
Residual variance & 0.133590 & \\
HAC variance & 0.086535 & \\
\hline
\end{tabular}

REMM, Cross border remittances; REG, number of registered mobile money accounts; MIGR stock of migrants; TO, trade openness; GDP, gross domestic product; CORR, control of corruption; POL, political stability and absence of violence; ROL, rule of law; HAC Heteroskedasticity and Autocorrelation Consistent; ADF, Augmented Dickey-Fuller.

$*, * *, * * *$, Indicates significance at $1 \%, 5 \%, 10 \%$, respectively

The results of the Kao cointegration test are also depicted (Table 4). The results of the Kao cointegration tests confirmed the existence of a cointegrating relationship amongst the variables. The null hypothesis of no cointegration was rejected at $1 \%$ level of significance. This implies that crossborder remittances have a long-run relationship with mobile money registration, stock of international migrants, GDP, TO and governance quality indicators. With the cointegrating relationship established, the next step involved estimating the empirical model using the DOLS and FMOLS techniques.

\section{Regression results and discussion}

The results of the combined regression estimations of the impact of mobile money on cross-border remittances are shown (Table 5). The estimates used demeaning to manage cross-sectional dependence in the panel in line with Ibrahim (2019) and Pedroni (1999). Demeaning reduces the unobserved common factors in the cross-section through mathematical cancellation (Pedroni 1999). The study's findings showed for both the DOLS and FMOLS estimations, the number of mobile money registered accounts (REGs) had a positive and strongly significant relationship with crossborder remittances (REMMs). Holding other variables constant, a unit increase in mobile money account registrations was observed to lead to an increase of 0.2795 in cross-border remittances under the DOLS estimation, whilst the coefficient for FMOLS was 0.6294.

The positive relationship between mobile money accounts registration and cross-border remittances also suggests that increased uptake of fintech innovations such as mobile money leads to a de facto improvement in regional financial integration through increased remittance flows across
TABLE 5: Combined regression estimations.

\begin{tabular}{|c|c|c|c|c|}
\hline \multirow[t]{2}{*}{ Variable } & \multicolumn{2}{|c|}{ DOLS } & \multicolumn{2}{|c|}{ FMOLS } \\
\hline & Coefficient & SE & Coefficient & SE \\
\hline REG & $\begin{array}{c}0.2795 * * * \\
(0.0036)\end{array}$ & 0.0900 & $\begin{array}{c}0.6294 * * * \\
(0.0000)\end{array}$ & 0.0785 \\
\hline MIGR & $\begin{array}{c}1.3803 * * * \\
(0.0000)\end{array}$ & 0.0224 & $\begin{array}{c}0.1856 * * * \\
(0.0000)\end{array}$ & 0.1228 \\
\hline TO & $\begin{array}{c}0.2097 * * * \\
(0.0082)\end{array}$ & 0.0750 & $\begin{array}{c}0.1168 \\
(0.1852)\end{array}$ & 0.0877 \\
\hline GDP & $\begin{array}{c}-0.1507 * * \\
(0.0371)\end{array}$ & 0.0697 & $\begin{array}{c}-0.3040 * * * \\
(0.0000)\end{array}$ & 0.0445 \\
\hline CORR & $\begin{array}{c}0.1666 \\
(0.5631)\end{array}$ & 0.0285 & $\begin{array}{l}-0.7052 \\
(0.5931)\end{array}$ & 0.1316 \\
\hline POL & $\begin{array}{c}-1.3683^{* * *} * \\
(0.0000)\end{array}$ & 0.2790 & $\begin{array}{c}-0.1983 * * * \\
(0.0000)\end{array}$ & 0.0181 \\
\hline ROL & $\begin{array}{c}-0.1057 \\
(0.7765)\end{array}$ & 0.3696 & $\begin{array}{c}0.5800 * * * \\
(0.0025)\end{array}$ & 0.0188 \\
\hline$N$ & 144 & - & 144 & - \\
\hline$R$-squared & 0.8980 & - & 0.9099 & - \\
\hline $\begin{array}{l}\text { Adjusted } R \\
\text { squared }\end{array}$ & 0.8935 & - & 0.9029 & - \\
\hline $\begin{array}{l}\text { Jarque-Bera } \\
\text { probability }\end{array}$ & 0.8620 & - & 0.3821 & - \\
\hline
\end{tabular}

Dependent variable: REMM

REMM, Cross border remittances; REG, number of registered mobile money accounts; MIGR, stock of migrants; TO, trade openness; GDP, gross domestic product; CORR, control of corruption; POL, political stability and absence of violence; ROL, rule of law; SE, standard error; DOLS, Dynamic Ordinary Least Squares; FMOLS, Fully Modified Ordinary Least Squares.

$*, * *, * * *$, Indicates significance at $1 \%, 5 \%, 10 \%$, respectively. Probabilities reported in brackets.

borders. Unlike Foreign Direct Investment (FDI) flows between countries, the de facto improvement in financial links resulting from mobile money adoption occurs at the household level as remittances are sent between individuals. Increased use of mobile money as a payments platform can therefore be associated with increased remittance payments across borders. For countries within sub-Saharan Africa, with lowly developed financial markets, this has the potential to create pools of savings and private capital across the region and deepen financial markets as remittances may also flow to the formal financial system. These findings are consistent with the assertion by Munyegera and Matsumoto (2016) that households, which adopt mobile money are more likely to receive remittances than households which do not. The finding also agrees with Batista and Vicente (2014), who attested to a shift towards fintech adoption through mobile money as a platform for remittances and other financial services. The findings (Table 5) also show the coefficient of migrants' stock (MIGR) was positive and significant at $1 \%$ in relation to remittances for both estimation techniques. A unit increase in the stock 
of migrants within a region was observed to lead to a 1.38 increase in the level of cross-border remittances under the DOLS estimation and 0.1856 for the FMOLS estimator. The results indicate that an increase in the number of migrants also has the potential to improve financial links between regional countries through an increase in cross-border remittances. The results confirm the role of migrants as a source for additional income, savings and agricultural inputs through the remittances they send (Batista \& Vicente 2020; Kikulwe et al. 2014). The TO coefficient was positive and significant at $1 \%$ under the DOLS estimation but was observed to be an insignificant determinant of cross-border remittances for the FMOLS estimator. However, in a comparison of DOLS and FMOLS, Kao and Chiang (2000) observed that for cointegrated panels, DOLS outperforms FMOLS; therefore, given two contrasting results between the two it would be prudent to accept the results of the DOLS estimator. Therefore, according to the DOLS results, a unit increase in exports and imports of goods and services results in an increase in cross-border remittances of 0.2097. Further examination (Table 7) shows GDP being negatively related to cross-border remittances for the DOLS estimator with a coefficient of 0.1507 . Similar results were obtained for the FMOLS estimator. These findings are consistent with the fact that remittances are mainly used to smoothen consumption patterns of recipients (Sharma 2009). Therefore, remittances are mainly used for education, health, agriculture and emergency aid purposes such as natural disasters (Batista \& Vicente 2020; Sharma 2009). The plausible explanation for the observed negative relationship is that in situations where national income increases (GDP), households may be less dependent on remittances, which may in turn reduce their flow to recipients. In such situations, an increase in national income may reduce dependence on relatives abroad and may result in a decrease in remittances. Findings on the relationship between governance indicators and cross-border remittances were mixed. The control of corruption was observed to be an insignificant determinant of cross-border remittances for both the DOLS and FMOLS estimators. However, the political stability coefficients were observed to be negative and significant at $1 \%$ in relation to remittances for both DOLS and FMOLS. On the other hand, the Rule of Law (ROL) coefficient was positive and insignificant for the FMOLS estimator and insignificant for the DOLS estimator. The findings on corruption are in contrast to previous studies by Ahmed (2013) and Tyburski (2014), who suggested that an improvement in the control of corruption discourages the flow of remittances across borders. Previous studies have alluded to the positive effect of political instability on migrant remittances as migrants try to cushion relatives back home from the negative effects of instability (Ajide \& Alimi 2019; Combes \& Ebeke 2011). This study's findings confirm these findings as a unit improvement in political stability was observed to lead to a reduction in remittances of 1.36 for the DOLS estimator and 0.1983 under FMOLS. Under a stable political environment, migrants do not have to increase the amount of remittances they send to relatives hence, the negative relationship between political stability and remittances. The findings suggest that better governance and an improved political climate have negative effects on the amount of remittances received. The ROL was observed to be an insignificant determinant of cross-border remittances for the DOLS estimator, implying that the extent of law enforcement may not be a deciding factor for migrants when sending remittances. However, the ROL coefficient for the FMOLS was positive and significant, suggesting better law enforcement improves cross-border remittances. For the diagnostics, both model fits were appropriate with an adjusted $R$-square of 0.89 for the DOLS estimator and 0.90 for FMOLS. An examination of serial correlation was carried out using the correlogram and all the $\mathrm{Q}$ statistics confirmed the absence of serial correlation. Individual coefficients of the Sub-Saharan Africa regions were also estimated and the results are shown in (Table 6).

TABLE 6: Region individual regression coefficients.

\begin{tabular}{|c|c|c|c|c|c|c|c|c|}
\hline \multirow[t]{2}{*}{ Dependent: REMM } & \multicolumn{4}{|c|}{ DOLS } & \multicolumn{4}{|c|}{ FMOLS } \\
\hline & Eastern Africa & Central Africa & Southern Africa & Western Africa & Eastern Africa & Central Africa & Southern Africa & Western Africa \\
\hline REG & $\begin{array}{c}0.1733 * * * \\
(0.0001)\end{array}$ & $\begin{array}{c}0.3404 * * * * \\
(0.0053)\end{array}$ & $\begin{array}{c}0.8332 * * * \\
(0.0000)\end{array}$ & $\begin{array}{c}1.0548 * * * \\
(0.0000)\end{array}$ & $\begin{array}{c}0.1350 * * * \\
(0.0064)\end{array}$ & $\begin{array}{c}0.1207 * * * \\
(0.0000)\end{array}$ & $\begin{array}{c}0.4620 * * * \\
(0.0020)\end{array}$ & $\begin{array}{c}0.1585 * * * \\
(0.0011)\end{array}$ \\
\hline MIGR & $\begin{array}{c}3.5485^{* * * *} \\
(0.0000)\end{array}$ & $\begin{array}{c}0.7612 * * * \\
(0.0012)\end{array}$ & $\begin{array}{c}-0.1166 * * \\
(0.0231)\end{array}$ & $\begin{array}{c}0.1878 * * \\
(0.0453) \\
.00\end{array}$ & $\begin{array}{c}0.2597 * * * \\
(0.0000)\end{array}$ & $\begin{array}{l}0.1286^{*} \\
(0.0771)\end{array}$ & $\begin{array}{c}0.6098 * * \\
(0.0325)\end{array}$ & $\begin{array}{l}0.1921^{*} \\
(0.0874)\end{array}$ \\
\hline TO & $\begin{array}{l}0.4749 * \\
(0.0925)\end{array}$ & $\begin{array}{c}0.2195 \\
(0.1455)\end{array}$ & $\begin{array}{l}-0.1974 \\
(0.2145)\end{array}$ & $\begin{array}{c}0.4702 * * \\
(0.0468)\end{array}$ & $\begin{array}{c}0.2415 * * * \\
(0.0000)\end{array}$ & $\begin{array}{c}0.3459 * * \\
(0.0532)\end{array}$ & $\begin{array}{c}0.7338 \\
(0.1047)\end{array}$ & $\begin{array}{c}0.3788 \\
(0.9847)\end{array}$ \\
\hline GDP & $\begin{array}{l}0.2135^{*} \\
(0.0879)\end{array}$ & $\begin{array}{c}0.2561 \\
(0.1087)\end{array}$ & $\begin{array}{c}0.1221 * * \\
(0.0372)\end{array}$ & $\begin{array}{l}-0.1525 \\
(0.8594)\end{array}$ & $\begin{array}{c}0.1899 \\
(0.6518)\end{array}$ & $\begin{array}{c}-0.1132 * * * \\
(0.0014)\end{array}$ & $\begin{array}{c}-0.6314 * * * \\
(0.0094)\end{array}$ & $\begin{array}{l}-0.1781 \\
(0.5478)\end{array}$ \\
\hline CORR & $\begin{array}{c}0.8509 \\
(0.1872)\end{array}$ & $\begin{array}{l}-1.4138 \\
(0.7964)\end{array}$ & $\begin{array}{c}0.4575 \\
(0.4236)\end{array}$ & $\begin{array}{c}-0.2885^{*} \\
(0.094)\end{array}$ & $\begin{array}{l}0.3104 * * \\
(0.0140)\end{array}$ & $\begin{array}{c}-0.3695^{*} \\
(0.0770)\end{array}$ & $\begin{array}{l}0.3311 * * \\
(0.0147)\end{array}$ & $\begin{array}{c}-1.679 \\
(0.1897)\end{array}$ \\
\hline POL & $\begin{array}{c}-0.3362 * * \\
(0.0289)\end{array}$ & $\begin{array}{c}-0.5366^{*} \\
(0.0629)\end{array}$ & $\begin{array}{c}-0.3402 * * * \\
(0.0057)\end{array}$ & $\begin{array}{c}0.1820 \\
(0.6247)\end{array}$ & $\begin{array}{l}-0.1689 \\
(0.1462)\end{array}$ & $\begin{array}{l}-0.8085^{*} \\
(0.0578)\end{array}$ & $\begin{array}{l}-0.3682^{*} \\
(0.0721)\end{array}$ & $\begin{array}{c}0.7262 \\
(0.1064)\end{array}$ \\
\hline ROL & $\begin{array}{l}-3.2000 \\
(0.3124)\end{array}$ & $\begin{array}{c}2.8239 \\
(0.2510)\end{array}$ & $\begin{array}{c}-6.406 \\
(0.4389)\end{array}$ & $\begin{array}{l}-1.0399 \\
(0.1046)\end{array}$ & $\begin{array}{c}-3.5015^{*} \\
(0.0981)\end{array}$ & $\begin{array}{l}0.1411 * * \\
(0.0104)\end{array}$ & $\begin{array}{l}-0.2621 \\
(0.1711)\end{array}$ & $\begin{array}{l}-0.4640 \\
(0.1624)\end{array}$ \\
\hline C & $\begin{array}{c}105.8172 * * * \\
(0.0017)\end{array}$ & $\begin{array}{c}-93.6443 * * * \\
(0.0052)\end{array}$ & $\begin{array}{c}153.6337 * * * \\
(0.0001)\end{array}$ & $\begin{array}{c}60.3603 * * * \\
(0.000)\end{array}$ & $\begin{array}{c}88.4177^{* * * *} \\
(0.0028)\end{array}$ & $\begin{array}{c}16.2164 * * * \\
(0.0059)\end{array}$ & $\begin{array}{c}-21.5770 * * * \\
(0.000)\end{array}$ & $\begin{array}{c}-9.4072 * * * \\
(0.000)\end{array}$ \\
\hline
\end{tabular}

REMM, Cross Border Remittances; REG, Number of Registered Mobile Money Accounts; MIGR, Stock of Migrants; TO, trade openness; GDP, gross domestic product; CORR, control of corruption; POL, political stability and absence of violence; ROL, rule of law; DOLS, Dynamic Ordinary Least Squares; FMOLS, Fully Modified Ordinary Least Squares; C, Constant.

$*, * *, * * *$, Indicates significance at $1 \%, 5 \%, 10 \%$, respectively. 
The individual coefficients (Table 6) show that mobile money adoption was consistently positive in its impact on crossborder remittances across all the four regions for both the DOLS and FMOLS estimations. The effect of migration was again observed to be positive, confirming findings by Munyegera and Matsumoto (2016) of the positive impact of mobile money adoption on remittances. In line with the combined regression coefficient, the individual coefficients for the regions confirmed the positive relationship between TO and remittances. The findings (Table 6) again show mixed results on the impact of GDP per region. Whilst the effect of GDP on remittances was observed to be positive in Eastern, Central and Southern Africa, Western Africa showed a negative relationship between the two is possible. The positive relationship may be attributed to an increase in economic growth and income, contributing to a greater amount of cross-border remittances as observed by Meyer and Shera (2017). On the other hand, the negative impact may be explained by the effects of reduced dependence and vulnerability on remittances in the case of economic growth, as observed by Sharma (2009) and Batista and Vicente (2020). The individual coefficients on the governance indicators also showed mixed results. Whilst the control of corruption was observed to be positively related to remittances in Eastern and Southern Africa; this was not the case for Central and Western Africa. The plausible explanation for the positive relationship is that in countries with more democratic space, citizens can demand greater accountability, which may improve the investment climate of those countries, leading to increased remittances (Bearce \& Park 2019; Tyburski 2014). On the other hand, the negative relationship may be attributed to the fact that an improvement in the control of corruption enables governments to increase spending on public services over private spending, leading to a reduction in vulnerability of citizens and less demand for remittances from relatives across borders. In line with the combined results, the individual coefficients for political stability largely showed a negative relationship between political stability and cross-border remittances, confirming the findings by Ajide and Alimi (2019) that political stability reduces dependence on remittances. Individual coefficients on the ROL were largely negative, suggesting that the ROL is not a determinant of cross-border remittances. The study also determined the direction of causality between mobile money, remittances and other factors. The results of the panel Granger causality tests are shown (Table 7).

Results of the Granger causality tests confirmed the presence of unidirectional causality from mobile money accounts to cross-border remittances, implying that an increase in mobile money accounts is associated with an increase in cross-border remittances. The findings are in line with the regressions estimations, which showed a positive and significant relationship between the two variables. Unidirectional causality was also observed between the stock of migrants and mobile money accounts, proving that an increase in the number of migrants has a corresponding incremental effect on mobile money
TABLE 7: Dumitrescu Hurlin Panel Granger causality tests.

\begin{tabular}{lccc}
\hline Null hypothesis & $W$-Stat & $Z$-Bar Stat & Probability \\
\hline $\begin{array}{l}\text { Remittances does not } \\
\text { homogeneously cause mobile } \\
\text { money accounts }\end{array}$ & 15.2090 & 1.42576 & 0.1539 \\
\hline $\begin{array}{l}\text { Mobile money accounts does not } \\
\text { homogeneously cause } \\
\text { remittances }\end{array}$ & 47.7467 & 9.96718 & $0.0000^{* * *}$ \\
$\begin{array}{l}\text { Mobile money accounts does not } \\
\text { homogenously cause GDP }\end{array}$ & 47.7467 & 9.96718 & $0.0000^{* * *}$ \\
$\begin{array}{l}\text { Gross domestic product does not } \\
\text { homogenously cause mobile } \\
\text { money accounts }\end{array}$ & 5.12672 & -1.22095 & 0.2221 \\
$\begin{array}{l}\text { Mobile money accounts does not } \\
\text { homogeneously cause migrant } \\
\text { stock }\end{array}$ & 4.76275 & -1.31649 & 0.1880 \\
$\begin{array}{l}\text { Migrant stock does not } \\
\text { homogeneously cause mobile } \\
\text { money accounts }\end{array}$ & 72.5923 & 16.4894 & $0.0000^{* * *}$ \\
$\begin{array}{l}\text { Mobile money accounts does not } \\
\text { homogeneously cause political } \\
\text { stability }\end{array}$ & 5.65329 & -1.08272 & 0.2789 \\
$\begin{array}{l}\text { Political stability does not } \\
\text { homogeneously cause mobile } \\
\text { money accounts }\end{array}$ & 10.5804 & 0.21070 & 0.8331 \\
$\begin{array}{l}\text { Rule of law does not } \\
\text { homogeneously cause mobile } \\
\text { money accounts }\end{array}$ & 9.62667 & -0.03967 & 0.9684 \\
$\begin{array}{l}\text { Mobile Money Accounts does not } \\
\text { homogenously cause rule of law }\end{array}$ & 9.98915 & 0.05549 & 0.9558 \\
$\begin{array}{l}\text { Trade openness does not } \\
\text { homogenously cause Mobile } \\
\text { Money Accounts }\end{array}$ & 14.9068 & 1.34642 & 0.1782 \\
$\begin{array}{l}\text { Mobile money accounts does not } \\
\text { homogenously cause trade } \\
\text { openness }\end{array}$ & 19.1119 & 2.45030 & $0.0143^{* * *}$ \\
\hline $\begin{array}{l}\text { GDP, gross domestic product. } \\
*, * * * * *, \text { Indicates significance at } 1 \%, 5 \%, 10 \%, \text { respectively. }\end{array}$ & & \\
\hline
\end{tabular}

accounts. This finding confirms the view that mobile money corridors play an important role of connecting migrants with their families in receiving countries (GSMA 2018). The study acknowledges the limitations of using registered accounts as a proxy for mobile money adoption, as it may not capture the actual intensity of mobile money flows in sub-Saharan Africa and may not be truly reflective of the usage of mobile money in the region.

\section{Conclusions and policy recommendations}

The study sought to investigate the impact of mobile money on regional financial integration in sub-Saharan Africa with cross-border remittances as the measure of regional financial integration. Study's findings showed that the adoption of mobile money has positively impacted cross-border remittances and improved de facto regional financial links between countries at the household level where remittances take place. Mobile money also has a unidirectional causality on cross-border remittances. The findings showed that the relationship between mobile money and cross-border remittances is highly pronounced. This attests to the fact that adoption of mobile money in sub-Saharan Africa is high and has in turn reduced levels of financial exclusion amongst different segments of society, including migrants. As such, whilst the global contribution of mobile money towards international remittances is recorded to be $10 \%$ globally, in sub-Saharan Africa the contribution has been observed to be $23 \%$ 
greater than the rest of the world and stands at 33\% (GSMA 2018). Furthermore, the findings also give credence to the fact that mobile money has been able to capture crossborder remittances, which were going through informal channels, resulting in observed cross-border remittances being higher than expected or anticipated international remittances (GSMA 2018). In this regard, the study concludes that mobile money adoption has regional benefits. As such, for sub-Saharan countries, the increased use of fintech innovations in cross-border remittances presents an opportunity to pool savings and private capital at the household level across the region and deepen financial markets as remittances are eased into formal financial markets. The study also uncovered the positive relationship between the stock of migrants and remittances and a unidirectional causality between stock of migrants and mobile money accounts. Therefore, we can conclude that an increase in the number of migrants also has the potential to improve financial links between regional countries through an increase in mobile money accounts and, correspondingly, cross-border remittances. However, UNCTAD (2018) observed that the bulk of the migrants are undocumented and do not have access to formal financial services. Therefore, increased adoption of fintech through mobile money offers the opportunity for increased access to financial services for these migrants and an opportunity to harness their savings into the mainstream economy. This calls for policy direction towards integrating mobile money and cross-border remittance platforms. Such policies can also be supported by removing barriers to access such as waivers for travel documents, proof of residence and permits when one intends to mobile money and crossborder remittance platforms. The study also confirmed the positive effects of TO on cross-border remittances. Therefore, sub-Saharan Africa should embrace policies that enhance trade across the continent as these have the potential of improving financial linkages and improving regional integration across the continent. Whilst combined results of the study support the view that control of corruption is an insignificant determinant of cross-border remittances, an assessment of the individual regional coefficients showed mixed results; at the same time, political stability was shown to be negatively related to remittances. Findings, therefore, support the view that improved governance reduces dependence on remittances by vulnerable communities in sub-Saharan Africa. Therefore, Sub-Saharan African countries should strive for better governance, control of corruption and political stability to ensure the provision of public services and reduce the vulnerability of their citizens. As proposed by Ahmed (2013) and Tyburski (2014), an improvement in the quality of governance is likely to ensure a well-functioning public services system. Therefore, there is a need to direct policy towards enhancing the quality of governance so that remittances will go towards investment in economic activities that support growth instead of paying for services, which governments should provide for their citizens.

\section{Acknowledgements Competing interests}

We acknowledge that none of the authors have any competing interest.

\section{Authors' contributions}

All authors contributed equally to the study.

\section{Ethical considerations}

Ethical clearance for the study was obtained from the University of Johannesburg's College of Business and Economic Ethics Committee 20SOM18.

\section{Funding information}

We confirm that no grants from any public or private agency were received to fund the study.

\section{Data availability}

The data used in the study is available upon formal request from the authors.

\section{Disclaimer}

We confirm that the views and opinions expressed in this study are entirely of the authors.

\section{References}

Ahmed, F.Z., 2013, 'Remittances deteriorate governance', Review of Economics and Statistics 95(4), 1166-1182. https://doi.org/10.1162/REST_a_00336

Ajide, F.M. \& Olayiwola, J.A., 2020, 'Remittances and corruption in Nigeria', Journa of Economics and Development 23(1), 19-33. https://doi.org/10.1108/jed-042020-0046

Ajide, K.B. \& Alimi, O.Y., 2019, 'Political instability and migrants' remittances into subSaharan Africa region', GeoJournal 84, 1657-1675. https://doi.org/10.1007/ s10708-018-9942-8

Ajide, K.B. \& Raheem, I.D., 2016, 'The institutional quality impact on remittances in the ECOWAS sub-region', African Development Review 28(4), 462-481. https:// doi.org/10.1111/1467-8268.12224

Aker, J.C., Prina, S. \& Welch, C.J., 2020, 'Migration, money transfers, and mobile money: Evidence from Niger', AEA Papers and Proceedings 110, 589-593. https:// doi.org/10.1257/pandp.20201085

Aker, J.C. \& Wilson, K., 2013, 'Can mobile money be used to promote savings? Evidence from Northern Ghana', SSRN Electronic Journal. https://doi.org/10.2139/ ssrn.2217554

Apiors, E. \& Suzuki, A., 2018, 'Mobile money, individuals' payments, remittances, and investments: Evidence from the Ashanti Region, Ghana', Sustainability 10(5), 1409. https://doi.org/10.3390/su10051409

Arner, D.W., Barberis, J.A. \& Buckley, R., 2016, 'The evolution of FinTech: A new postcrisis paradigm', Georgetown Journal of International Law 47(4), 1271-1319. https://doi.org/10.2139/ssrn.2676553

Asongu, S.A. \& Odhiambo, N.M., 2019, 'Governance, capital flight and industrialisation in Africa', Journal of Economic Structures 8(1), 1-22. https://doi.org/10.1186/ s40008-019-0170-2

Asuming, P.O., Osei-Agyei, L.G. \& Mohammed, J.I., 2019, 'Financial inclusion in subSaharan Africa: Recent trends and determinants', Journal of African Business 20(1), 112-134. https://doi.org/10.1080/15228916.2018.1484209

Batista, C. \& Vicente, P.C., 2014, 'Introducing mobile money in rural Mozambique: Evidence from a field experiment', SSRN Electronic Journal. https://doi. org/10.2139/ssrn.2384561

Batista, C. \& Vicente, P.C., 2020, Is mobile money changing rural africa? Evidence from a field experiment *, viewed 03 November 2020, from www.gsma.com.

Bearce, D.H. \& Park, S., 2019, 'Why remittances are a political blessing and not a curse', Studies in Comparative International Development 54(1), 164-184. https:// doi.org/10.1007/s12116-018-9277-y 
Breusch, T.S. \& Pagan, A.R., 1980, 'The Lagrange multiplier test and its applications to model specification in econometrics', The Review of Economic Studies 47(1), 239. https://doi.org/10.2307/2297111

Buchak, G. Matvos, G., Piskorski, T. \& Seru, A., 2018, 'Fintech, regulatory arbitrage, and the rise of shadow banks', Journal of Financial Economics 130(3), 453-483. https://doi.org/10.1016/j.jfineco.2018.03.011

Bush, G., 2015, 'Capital flows, de jure vs. de facto financial openness', SSRN Electronic Journal. https://doi.org/10.2139/ssrn.2688584

Combes, J.L. \& Ebeke, C., 2011, 'Remittances and household consumption instability in developing countries', World Development 39(7), 1076-1089. https://doi. org/10.1016/j.worlddev.2010.10.006

David, B., Dana, D. \& Abel, F., 2013, 'On the effect of mobile phone on migrant remittances: A closer look at international transfers', Electronic Commerce Research and Applications 12(4), 280-288. https://doi.org/10.1016/j elerap.2013.01.002

Demirgüç-Kunt, A., Klapper, L. \& Bank, T.W., 2012, Financial inclusion in Africa: An overview, viewed 15 October 2019, from http://econ.worldbank.org.

Diniz, E.H., Porto de Albuquerque, J. \& Cernev, A.K., 2017, 'Mobile money and payment A literature review based on academic and practitioner-oriented publication (2001-2011)', SSRN Electronic Journal. https://doi.org/10.2139/ssrn.2924669

Dorfleitner, G., Hornuf, L., Schmitt, M. \& Weber, M., 2017, 'Definition of FinTech and description of the FinTech industry', in FinTech in Germany, pp. 5-10, Springe International Publishing, New York. https://doi.org/10.1007/978-3-319-54666-7_2

Dumitrescu, E.I. \& Hurlin, C., 2012, 'Testing for Granger non-causality in heterogeneous panels', Economic Modelling 29(4), 1450-1460. https://doi.org/10.1016/j. econmod.2012.02.014

Effiong, E.L. \& Asuquo, E.E., 2016, Munich Personal RePEc Archive Migrants Remittances, Governance and Heterogeneity, MPRA paper 74753.

Ernst and Young, 2019, Report EY Global Financial Services Markets Executive Chair and EY Asia-Pacific Financial Services Regional Managing Partner.

FinMark Trust, 2016, Cross-border remittances, viewed 18 October 2019, from https:// finmark.org.za/system/documents/files/000/000/273/original/cross-borderremittances-2016.pdf?1603790268

Gehringer, A., 2014, 'Financial liberalisation, financial development and productivity growth: An overview', International Journal of Monetary Economics and Finance 7(1), 40-65. https://doi.org/10.1504/IJMEF.2014.063841

GSMA, 2018, Mobile money: Competing with informal channels to accelerate the digitalization of remittances, Report, viewed 16 April 2021, from https://www. gsma.com/mobilefordevelopment/wp-content/uploads/2018/05/Mobile Money_Competing_with_informal_channels_to_accelerate_the_digitisation_of_ remittances.pdf.

GSMA, 2019a, GSMA mobile money adoption survey, FinDev Gateway, viewed 21 July 2020, from https://www.findevgateway.org/data/gsma-mobile-money-adoptionsurvey.

GSMA, 2019b, State of the mobile money industry in Africa.

Ibrahim, S.M., 2019, Fostering innovation in South Asia: Evidence from FMOLS and causality analysis, MPRA Paper 96193, University Library of Munich, Germany.

IFC, 2019, Reinventing business through disruptive technologies, viewed 15 Octobe 2019, from https://www.ifc.org/wps/wcm/connect/publications ext content/ ifc_external_publication_site/publications_listing_page/reinventing-business.

International Finance Corporation, 2018, 'Digital Access: The Future of Financial Inclusion in Africa' Borsa Istanbul Review, November 2-3, viewed n.d., from https://www.ifc.org/wps/wcm/connect/aa5e09c7-121e-4588-803a52 ef56b846b2/201805 Digital-Access The-Future-of-Financial-Inclusion-inAfrica_v1.pdf?MOD=AJPERES

Jong-Moon, J. \& Hyunju, P., 2016, Mobile money in sub-Saharan Africa and its implications, viewed 22 July 2020, from http://data.worldbank.org.

Kao, C., 1999, 'Spurious regression and residual-based tests for cointegration in pane data', Journal of Econometrics 90(1), 1-44. https://doi.org/10.1016/S03044076(98)00023-2

Kao, C. \& Chiang, M.H., 2000, 'On the estimation and inference of a cointegrated regression in panel data', Advances in Econometrics 15, 179-222. https://doi. org/10.1016/S0731-9053(00)15007-8

Kikulwe, E.M., Fischer, E. \& Qaim, M., 2014, 'Mobile money, smallholder farmers, and household welfare in Kenya', PLoS One 9(10), e109804. https://doi.org/10.1371/ journal.pone.0109804

Kirui , B.K., 2020, The role of mobile money in international remittances: Evidence from sub-Saharan Africa, Working Paper.

Levin, A., Lin, C.-F. \& James Chu, C.-S., 2002, 'Unit root tests in panel data: Asymptotic and finite-sample properties', Journal of Econometrics 108(1), 1-24. https://doi. org/10.1016/S0304-4076(01)00098-7

Maddala, G.S. \& Wu, S., 1999, 'A comparative study of unit root tests with panel data and a new simple test', Oxford Bulletin of Economics and Statistics 61(S1), 631652. https://doi.org/10.1111/1468-0084.0610s1631

Mahmoud, Z., 2019, A service of zbw Leibniz-Informationszentrum Wirtschaf Leibniz Information Centre for Economics Standard-Nutzungsbedingungen Determinants of mobile money adoption, viewed 30 November 2020, from www.econstor.eu.

Marshall, T., 2007, (PDF) A new model for explaining technology usage: The quadratic usage model, viewed 19 October 2019, from https://www.researchgate.net/ publication/296112510_A_New_Model_for_Explaining_Technology_Usage The_Quadratic_Usage_Model.
Mastercard, 2018, Mobile money driving financial inclusion in sub-Saharan Africa viewed 16 October 2019, from https://www finextra.com/pressarticle/73913/ mobile-money-driving-financial-inclusion-in-sub-saharan-africa.

Mention, A.L., 2019, 'The future of Fintech', in Research technology management, pp. 59-63, Taylor and Francis Inc. https://doi.org/10.1080/08956308.2019.1613123

Meyer, D. \& Shera, A., 2017, 'The impact of remittances on economic growth: An econometric model', EconomiA 18(2), 147-155. https://doi.org/10.1016/j econ.2016.06.001

Mirabaud, N., 2009, 'Migrants' remittances and mobile transfer in emerging markets', International Journal of Emerging Markets 4(2), 108-118. https://doi org/10.1108/17468800910945756

Mothobi, O. \& Grzybowski, L., 2016, Infrastructure deficiencies and adoption of mobile money in sub-Saharan Africa *, viewed 22 July 2020, from www.itu.int.

MTN, 2020, Mobile financial services - MTN Group, viewed 23 July 2020, from https:// www.mtn.com/what-we-do/mobile-financial-services/.

Munyegera, G.K. \& Matsumoto, T., 2016, 'Mobile money, remittances, and household welfare: Panel evidence from rural Uganda', World Development 79, 127-137. https://doi.org/10.1016/j.worlddev.2015.11.006

Naghavi, N., 2019, Sub-Saharan Africa mobile money: Diverse use cases, enabling environment boost adoption, Center for Financial Inclusion, viewed 21 July 2020 from https://www.centerforfinancialinclusion.org/sub-saharan-africa-mobilemoney-diverse-use-cases-enabling-environment-boost-adoption.

Nantege, H.B., 2015, The threat of mobile money services to the financial performance of commercial banks in Uganda: A case of Stanbic Bank, viewed 18 October 2019, from http://makir.mak.ac.ug/handle/10570/5984.

Ogunniyi, A.I., Mavrotas, G., Olagunju, K.O., Fadare, O. \& Adedoyin, R., 2020, 'Governance quality, remittances and their implications for food and nutrition security in Sub-Saharan Africa', World Development 127, 104752. https://doi. org/10.1016/j.worlddev.2019.104752

Orange, 2020, Orange Money, emblematic business activity for the Group - orange. com, viewed 23 July 2020, from https://www.orange.com/en/Group/Activities/ Orange-Financial-Services/Folder/Orange-Money?a=

Pasti, F., 2017, Mobile money as a driver of financial inclusion in sub-Saharan Africa GSMA, viewed 16 October 2019, from https://www.gsma.com/ mobilefordevelopment/programme/mobile-money/mobile-money-drivermobilefordevelopment/programme/m
financial-inclusion-sub-saharan-africa/.

Pedroni, P., 1999, 'Critical values for cointegration tests in heterogeneous panels with multiple regressors', Oxford Bulletin of Economics and Statistics 61(s1), 653-670. https://doi.org/10.1111/1468-0084.0610s1653

Pedroni, P., 2000, Fully modified OLS for heterogeneous cointegrated panels, Department of Economics Working Papers, viewed 30 November 2020, from https://ideas.repec.org/p/wil/wileco/2000-03.html.

Pesaran, M.H., 2004, 'General Diagnostic Tests for Cross Section Dependence in Panels', Cambridge Working Papers in Economics 0435, Faculty of Economics, University of Cambridge, Cambridge.

Pesaran, M.H., Shin, Y. \& Smith, R.P., 1999, 'Pooled mean group estimation of dynamic heterogeneous panels', Journal of the American Statistical Association 94(446), 621-634. https://doi.org/10.1080/01621459.1999.10474156

Pesaran, M.H., Ullah, A. \& Yamagata, T., 2008, 'A bias-adjusted LM test of error crosssection independence', The Econometrics Journal 11(1), 105-127. https://doi org/10.1111/j.1368-423X.2007.00227.x

Philippon, T., 2019, On Fintech and Financial Inclusion, NBER Working Papers 26330 National Bureau of Economic Research, Inc.

Phillips, P.C.B. \& Hansen, B.E., 1990, Estimation and inference in models of cointegration: A simulation study, viewed 30 November 2020, from https:// econpapers.repec.org/RePEc:cwl:cwldpp:881.

Phillips, P.C.B. \& Moon, H.R., 1999, Nonstationary panel data analysis: An overview of some recent developments, Cowles Foundation Discussion Papers, viewed 30 November 2020, from https://ideas.repec.org/p/cwl/cwldpp/1221.html.

Rea, S.C. \& Nelms, T.C., 2017, Mobile money: The first decade, Working Paper 2017-1, Institute for Money, Technology and Financial Inclusion.

Ricciardulli, J., 2019, 'Do remittances encourage poor governance practices?', UGA Journal of Economics 1(2), 1-25.

Sharma, K., 2009, The impact of remittances on economic insecurity, viewed 01 December 2020, from http://www.un.org/esa/desa/papers.

Stock, J.H. \& Watson, M.W., 1993, 'A simple estimator of cointegrating vectors in higher order integrated systems', Econometrica 61(4), 783-820. https://doi. higher order integrated
org/10.2307/2951763

Sy, A.N., Maino, R., Massara, A., Perez-Saiz, H. \& Sharma, P., 2019, FinTech in SubSaharan African countries: A game changer?, IMF, Departmental Paper No. 19/04, viewed 17 October 2019, from https://www.imf.org/en/Publications/ Departmental-Papers-Policy-Papers/Issues/2019/02/13/FinTech-in-Sub-SaharanAfrican-Countries-A-Game-Changer-46376.

Sy, A.N.R., 2019, How mobile money can lead a fintech revolution in Africa, World Economic Forum, viewed 21 July 2020, from https://www.weforum.org/ agenda/2019/02/fintech-in-sub-saharan-africa-a-potential-game-changer.

Tyburski, M.D., 2014, Curse or cure? Remittances and corruption in the developing world, viewed 29 November 2020, from https://dc.uwm.edu/etd/546.

UNCTAD, 2018, Migration for structural transformation patterns and trends of migratio, Economic Development in Africa Report Chapter 2 Patterns and Trends of Migration, viewed 5 January 2021, from https://unctad.org/webflyer/ economic-development-africa-report-2018 
Villasenor, J.D., West, D.M. \& Lewis, R.J., 2015, The 2015 brookings financial and digital inclusion project report: Measuring progress on financial access and usage, p. 186, Center for Technology Innovation at BROOKINGS, viewed 16 October 2020, from http://www.brookings.edu/ /media/Research/Files/ Reports/2015/08/financial-digital-inclusion-2015-villasenor-west-lewis/
fdip2015.pdf.

Vodafone, 2020, M-Pesa, viewed 22 July 2020, from https://www.vodafone.com/ what-we-do/services/m-pesa.
World Bank, 2018, Global financial development report, viewed 16 April 2021, from https://openknowledge.worldbank.org/bitstream/handle/10986/28482/ 9781464811487. pdf?sequence=11\&isAllowed $=y$.

Ziesemer, T., 2009, (7) (PDF) Remittances, lagged dependent variables and migration stocks as determinants of migration from developing countries, viewed 30 November 2020, from https://www.researchgate.net/publication/46433668 Remittances_lagged dependent variables_and_migration_stocks_as determinants_of migration from developing_countries. 